\title{
Effect of the Temporary Parasite of Praniza Larvae of Gnathiidae Isopod, A Gill Chamber Parasite of the Coral Reef Fishes, Gulf of Mannar
}

\author{
Chelladurai $\mathbf{G}^{1}$, Subbulakshmi $\mathrm{S}^{2}$ \\ ${ }^{1 *}$ Department of Zoology, G.Venkatasamy Naidu College, Kovilpatti, Tuticorin ,Tamil Nadu, India \\ ${ }^{2}$ Department of Microbiology, Kamaraj College, Tuticorin, Tamil Nadu, India
}

*Corresponding author: Chelladurai G, Department of Zoology GVN College, (Kovilpatti), Tuticorin(Dst),TamilNadu,India; Email: gcd.zoology@gmail.com.

Citation: Chelladurai G (2017) Effect of the temporary parasite of praniza larvae of gnathiidae isopod, a gill chamber parasite of the coral reef fishes, gulf of mannar, J Fish Aquac Dev 2017: JFAD 104.

Received Date: 01 February, 2017; Accepted Date: 13 February, 2017; Published Date: 20 February, 2017.

\begin{abstract}
Praniza larvae of Gnathiidae isopod were collected from south east coast of India, Gulf of Mannar. It was abundantly present in the gill chamber of coral reef fishes. The total of 133 fish species were examined and among them 78 fishes have found to be affected by the parasitic infection. This infection may lead the coral reef fishes to get affecting the efficiency if respiration. And the major problem is that this may also lead to immediate death. The maximum and minimum prevalence were also observed. The present study, infestation satus of Pranzia larvae of gnathiidae isopod on coral reef fishes from southeast coast of India.
\end{abstract}

Keywords: Ganthiidae, Coral reef fishes, Southeastcoast of India

\section{Introduction}

Parasites are common on fishes and can directly affect hosts at individual and population levels by reducing growth and reproduction or indirectly by altering behaviour [1]. A common ectoparasite found in reef fishes is gnathiid isopods. The high prevalence, attack rate and mobility of such blood-feeding ectoparasites on adult fishe [2]. These temporary ectoparasites have a polymorphic and biphasic life cycle. There are three larval stages with each stage having two forms, namely praniza and zuphea. The praniza is a replete, haematophagous phase ectoparasitic on fish, while the zuphea is the unfed benthic dweller phase [3]. The free-living adults do not feed and are usually hidden in a cavity or sponge where reproduction will occur. Gnathiids attached to various sites on the fish including the gills, behind the eyes, mouth, body, and on the dorsal, caudal and pectoral fins. On first contact with a gnathiid, fish would often become agitated and try to shake off the parasite. Often, swimming ability was impaired when Gnathiasp. attached to individuals, particularly on the fins or gill. The larvae of gnathiid isopods are some of the most common parasites of adult reef fish [4]. Gnathiids are mobile temporary parasites classified as micropredators since they do not ingest the whole animal and kill it, but rather take small meals and then leave their prey [5]. Presently there are 182 identified species of gnathiids reported from the world oceans. The Larvae, adult females and males differ considerably in their shape and behaviour [6]. There is only very limited studies were available especially parasite diversity on marine reef fishes. So that, This study is specifically aimed to investigate the infestations and hosts distribution of Gnathia sp from southeast coast of India, TamilNadu.

\section{Materials and Methods}

Fishes were caught bygillnet and trawlers from landed at Tharuvaikulam coast (Latitude $80 \quad 19^{\prime} \mathrm{N}$ Longitude $780 \quad 21^{\prime} \mathrm{E}$ ), which is located at south east coast of India (Figure .1). 
Citation: Chelladurai G (2017) Effect of the temporary parasite of praniza larvae of gnathiidae isopod, a gill chamber parasite of the coral reef fishes, gulf of mannar, J Fish Aquac Dev 2017: JFAD 104.

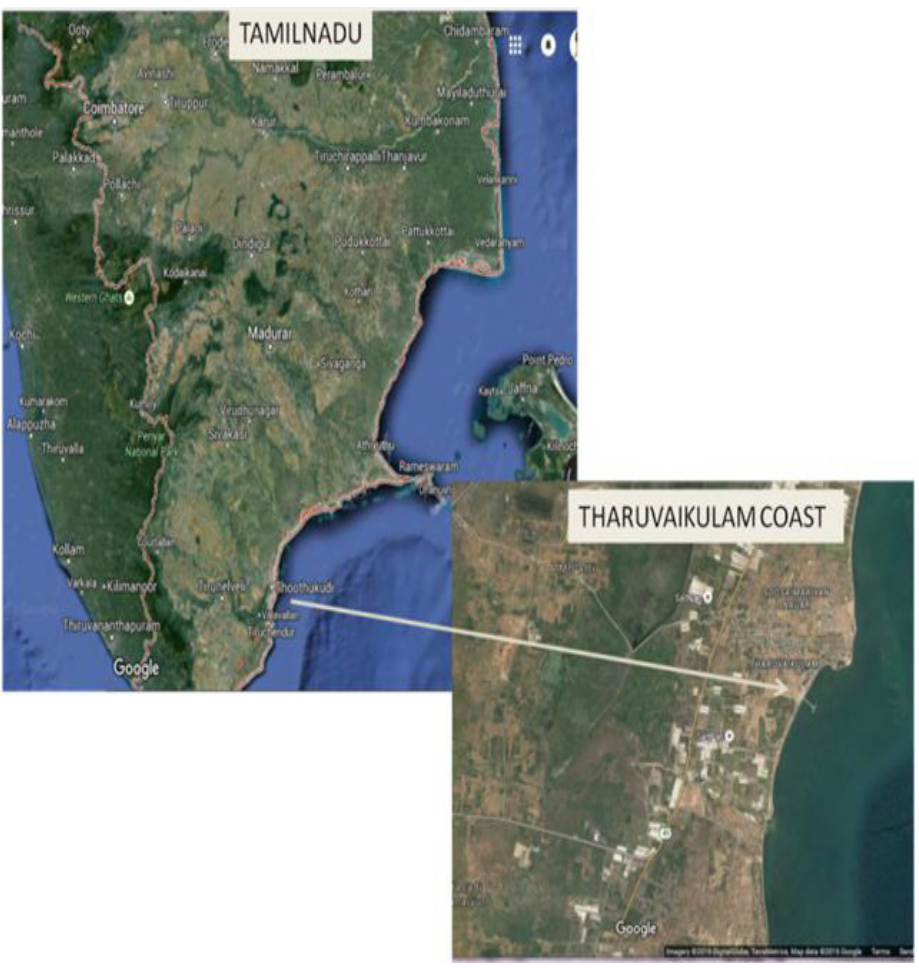

Figure 1: Map showing the study area.

They were collected during January 2015 to June 2015 and were transported to the laboratory. In total 133 fish specimens belonged to five genera and six species were examined, including, Adudefduf sp, Alectis indicus, Chaetodon collare, C. decussates, C. octofasciatus, Cheilinus chlerousus, Halichoeres zeylonicus, Heniochus acuminatus, Parupenus indicus, Sargocentron rubrum, Siganus javus, Scolopsis vosmeri. The host nomenclature and fish taxonomy are according to Fish Base Froese and Pauly [7]. After capturing, the fishes were placed on ice for approximately $6 \mathrm{hr}$ and the body surface, fins, gills, mouth of each fishes were examined. The gill arches were preserved in $70 \%$ ethanol and later examined with the aid of a dissecting microscope. The parasites of this Gnathiidae isopod were removed and preserved in $70 \%$ ethanol and deposited at the Department of Zoology, kamaraj College, Tuticorin, Tamil Nadu, India. The host species examined, host species infested, Prevalence (\%), Mean intensity and total number of parasites were calculated [8]. The identification of parasites was completed according to various authors [9-11]. The host fishes were not preserved.

\section{Result and Discussion}

During the investigations on gnathia sp isopod were found in the gill chamber of coral reef fishes (Figure 2).

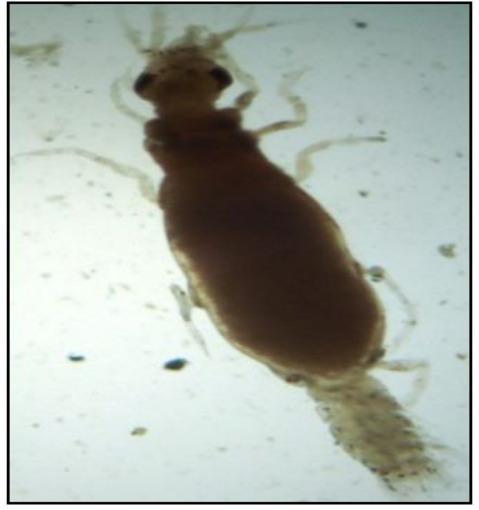

Figure 2: Dorsal view of Gnathia sp.
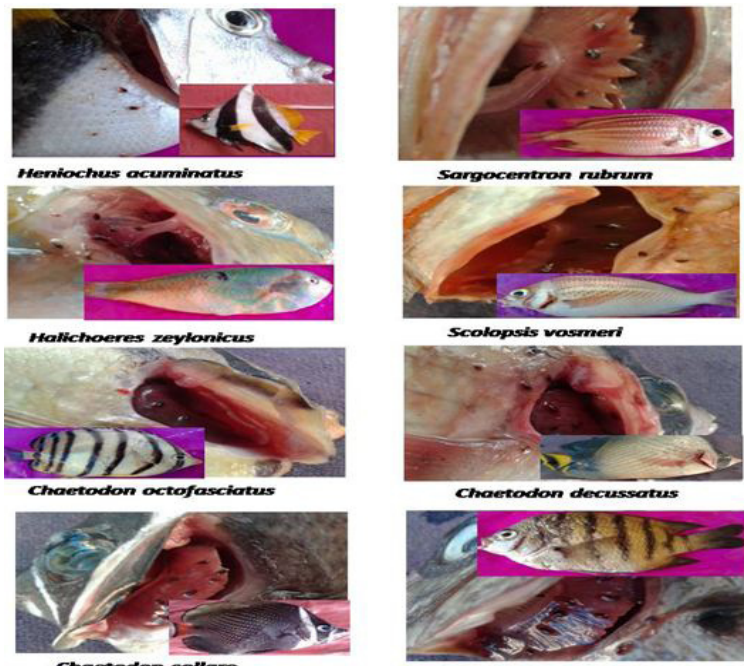

Scolopsis vosmeri

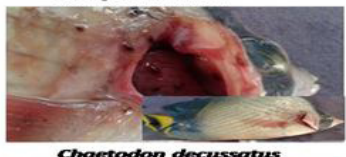

Chaetodon decussatus
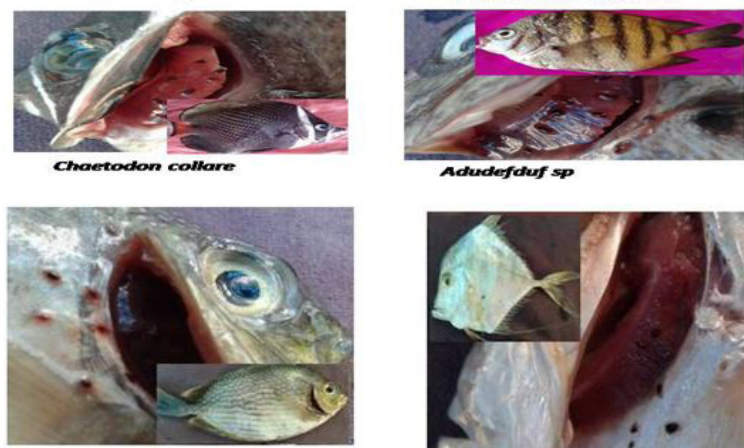

Siganus javus

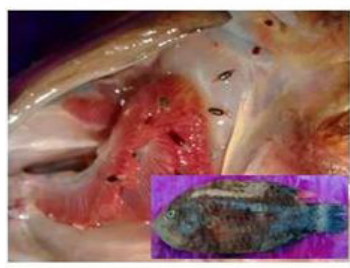

Cheilinus chlerousus
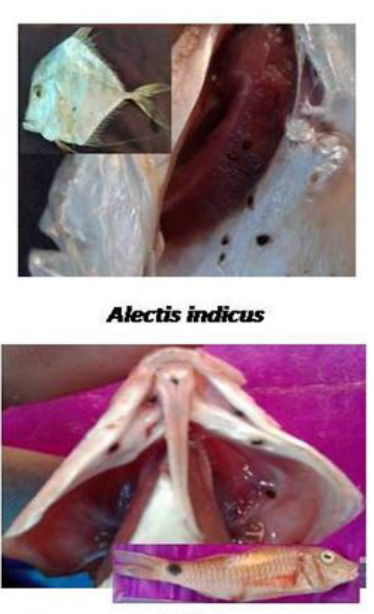

Parupenus indicus

Figure 2: Gnathia sp in the gill chamber of coral reef fishes from Southeast coast of India 
Citation: Chelladurai G (2017) Effect of the temporary parasite of praniza larvae of gnathiidae isopod, a gill chamber parasite of the coral reef fishes, gulf of mannar, J Fish Aquac Dev 2017: JFAD 104.

The maximum parasite have been found 68 out of 23 species of $\mathrm{H}$. acuminatus and minimum parasite have been found 7 out of 5 species of Alectis indicus. The microscopic view of larvae of gnathia sp was showed in Figure 3. In total 133 fishes species were collected and 78 fishes had affected parasitc infection. Infestation values: Number of fish examined, number of fish infested, prevalence (\%), Mean intensity, Relative density and total number of parasites were given in (Table 1).

\begin{tabular}{|c|c|c|c|c|c|c|c|}
\hline S.NO & Name of the Fish species & NFE & NFI & NP & MI & Prevalence $(\%)$ & Relative density \\
\hline 1 & Adudefduf sp & 5 & 3 & 8 & 3 & 60 & 1.6 \\
\hline 2 & Alectis indicus & 5 & 1 & 7 & 7 & 20 & 1.4 \\
\hline 3 & Chaetodon collare & 13 & 5 & 16 & 3 & 38.4 & 1.2 \\
\hline 4 & C. decussatus & 17 & 12 & 31 & 3 & 70.5 & 1.8 \\
\hline 5 & C. octofasciatus & 13 & 6 & 19 & 3 & 46.1 & 1.4 \\
\hline 6 & Cheilinus chlerousus & 5 & 2 & 11 & 6 & 40 & 2.2 \\
\hline 7 & Halichoeres zeylonicus & 8 & 3 & 14 & 5 & 37.5 & 1.7 \\
\hline 8 & Heniochus acuminatus & 23 & 18 & 68 & 4 & 78.2 & 2.9 \\
\hline 9 & Parupenus indicus & 16 & 15 & 41 & 3 & 93.7 & 2.5 \\
\hline 10 & Sargocentron rubrum & 11 & 7 & 21 & 1 & 63.6 & 1.9 \\
\hline 11 & Siganus javus & 9 & 3 & 15 & 5 & 33.3 & 1.6 \\
\hline 12 & Scolopsis vosmeri & 8 & 3 & 12 & 4 & 37.5 & 1.5 \\
\hline
\end{tabular}

Table 1: Parasitological index of Gnathia sp. collected from Southeast Coast of India.

$\mathrm{NFE}=$ Number of Fish Examined; NFI $=$ Number of fish infested; $\mathrm{P}=$ Prevalence (\%); MI= Mean intensity ; NP= Total Number of Parasites

The maximum prevalence of parasite were observed in Parupenus indicus $(93.7 \%)$ and minimum prevalence of parasite were observed in Alectis indicus (20\%) respectively. The parasites of Gnathia sp may occupy the entire branchial chamber of the host may produce pressure on the gill surface and thus affecting the efficiency of respiration. Although, the infestation may cause immediate death, it will affected the normal growth of the host fishes particularly degeneration of sexual organs. They may lead to economic loss of fishes. Reported the general parasitic infection of fin and shell fishes mainly depend upon host factors such as age, size, sex, maturity, stage, behavior, feeding and breeding, life cycle and particularly factors [12]. Gnathiids can be pathogenic; these effects include anemia, mild to serve tissue damage and at worst, mortality at high densities [13]. According the several authors reported the gnathidae isopod larvae are one of the most common ecto-parasite found in coral reef fishes [14]. The high abundance of gnathiids in some cases exceeding 200 per host, on a single elasmobranch. In an in depth study on the pathology associated with gnathiid infection on epaulette shark [4]. According to [15] gnathiidae isopods are the most common food found in the diet of cleaner fish, and are also eaten by clear shrimp [16]; Grutter and [17] reported that gnathiid life cycle and gnathiidae host interaction are essential on understanding the factors that influence transmission of haemogregarines and may include such vector-derived factors such as density, prevalence, number of parasites on attachments' of host.

\section{Conclusion}

This study suggest it is clear that the worst of fish on account of the infestation of gnathia sp on coral reef fishes are succumbed to the attack of isopod parasites. Although, the infestation did not caus death, it had no affected the normal growth of the host fishes.

\section{Conflict of Interest Statement}

We declare that we have no conflict of interest

\section{Acknowledgments}

Authors are thankful to INCOIS-OSF Project (Grant No: F\&A:OSF/A2:XII:014.Dt06/06/2014), Ministry of Earth Sciences (MoES) (Government of India) for providing financial support and Kamaraj College, Manonmaniam Sundaranar University, Tuticorin for providing facilities and encouragement.

\section{References}

1. Fenton A, Rands SA (2006) The impact of parasite manipulation and predator foraging behavior on predator-prey communities. Ecology 87: 2832-2841.

2. Jones CM, Grutter AS (2007) Variation in emergence of parasitic and predatory isopods among habitats at Lizard Island, Great Barrier Reef. Marine Biology 150: 919-927.

3. Smit NJ, Davies AJ (2004) The curious life-style of the parasitic stages of gnathiid isopods. Advances in Parasitology 58: 289-391.

4. Grutter AS, Poulin R (1998) Intraspecific and interspecific relationships between host size and the abundance of parasitic larval gnathiid isopo- 


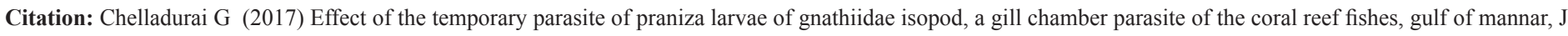
Fish Aquac Dev 2017: JFAD 104.

ds on coral reef fishes. Marine Ecology Progress Series 164: 263-271.

5. Lafferty KD, Morris K (1996) Altered behavior of parasitized killifish increases susceptibility to predation by bird final hosts. Ecology 77 : 1390-1397

6. Kensley B, Schotte M, Poore GCB (2009) Gnathiid isopods (Crustacea: Isopoda: Gnathiidae), mostly new, from the Indian Ocean. Proceedings of the Biological Society of Washington 122: 32-51.

7. Froese R, Pauly D (2000) FishBase: World Wide Web Electronic Publication.

8. Bush AO, Lafferty KD, Lotz JM, Shostak AW (1997) Parasitology meet ecology on its own terms: Margolis et al. revisited. J. Parasitol 83: 575-583.

9. Möller H, Anders K (1986) Diseases and Parasites of Marine Fishes. Verlag Heino Möller, Kiel.

10. Kabata Z (1970) Diseases of Fishes: Book I. Crustaceans Enemies of Fishes. T.F.H. Publications at New Jersey US.

11. Naylor E (1972) British Marine Isopods. Academic Pres at New York.
12. Ravichandran S, Rameshkumar G, Balasubramanian T (2010) Infestation of isopod parasites in commercial marine fishes, J Parasit Dis 34: 97-98.

13. Lester RJG, Roubal FR (1995) Phylum Arthropoda In : Fish disease and Disorder, Protozan and Metazoan infections, Wallingford,UK CABI Publishing.

14. Tinsley MC, Reilly SD (2002) Reproductive ecology of the saltmarshdwelling marine ectoparasite Paragnathia formica (Crustasea:Isopoda). J Mar Biol Assoc UK 82: 79-84

15. Grutter AS (1996) Parasite removal rates by the cleaner wrasse Labroides dimidiatus. Mar Ecol Prog Ser 130: 61-70.

16. Mckiernan JP, Alexandra S, Grutter AS, Davies AJ (2005) Reproductive and feeding ecology of parasitic gnathiid isopods of epaulette sharks (Hemiscyllium ocellatum) with consideration of their role in the transmission of a haemogregarine. Int J Parasitol 35: 19-27.

17. Grutter AS, Hendrikz J (1999) Diurnal variation in the abundance of juvenile parasitic gnathiid isopods on coral reef fish: implications for parasite-cleaner fish interactions. Coral Reefs 18: 187-191. 